\title{
Digital Public Sphere of Bangladesh: Religious Confrontation and Domination
}

\author{
Md. Sayeed Al-Zaman*
}

\begin{abstract}
The interrelationship between a privileged group and a deprived group within any given framework, that could be a society or organization, is complex in nature. When dominant voice rises, "inferior" group affected by the "spiral of silence". Irrespective to societies, the picture has been same throughout the history. However, modern world is often exaggerated as a "democratic utopia" which is thriving surpassing agony and inequality. All the dreams are becoming mirage as people across the globe are withdrawing their consent from peaceful coexistence in certain areas of life, rather inclining more rigid doctrines onward, such as authoritarianism, militarism. In the root of these propensities, lust for power and prosperity suppressing others are one key reason. In Bangladesh, cocultures, namely woman, indigenous communities, religious minorities, and so on are the victim of oppression and denigration. Of them, religious minorities are wide thought to be the most persecuted co-cultures in contemporary socio-political context of Bangladesh. In digital age, something extraordinary happens which has been entitled as "digital public sphere". In fact, it has been sensed previously that this precise space would alleviate the prior condition of other belief groups. Most of the notion goes in vain since the rise of a unique digital piety and online-based Islamic fanaticism that often govern the whole digital public sphere of Bangladesh. In this study, the contents and communicative patterns among religious communities have been identified which affirm the digital media-initiated violence is pushing the minorities on the edge.
\end{abstract}

Keyword: Digital; Islam; extremism; Bangladesh; internet; communalism; minority.

\section{Introduction}

Ethics is wonderful while it lies only between the chapters of books as it is yet to function perfectly amid human society. Although people through ages dreamt of living in a society where no disparity would act, no individuals and group would be deceived and deprived, and none would have to endure agony. Meanwhile, during the past 600 years, the world has experienced 3708 wars fought between belligerent groups which cost millions of human lives (Roser, 2018). Undoubtedly, one of the primary reasons to wage a war is the behavior of subduing others. However, this exercise has currently been failing worldwide as sense of freedom and human rights have prevailed. Even in Europe after the Catalonian declaration of independence, which often mistakenly interpreted as the so-called "Clash of Civilization", at least 22 similar "pro-independence zones" were identified, and many of them are forwarded in the question of emancipation solely based on their cultural identities (Henley et al., 2017). Such stances prove two contemporary aptness: (a) sense of identity, belongingness, and

\footnotetext{
* Md. Sayeed Al-Zaman, researcher of Digital Sociology. Currently serving as an Executive Editor at Advanced Services for the People's Economy, Culture and technology (ASPECT) Trust. Email: ovi.sayeed@yahoo.com
} 
nationhood is on the rise worldwide, and thus people are onward a kind of "tribalism" once again; and (b) suppression and omission against minor groups would not work further. Following the second proposition, coexistence and co-cultural environment of Bangladesh in digital age needs to be assessed.

To list co-cultural communities based on distinguished categories, it would be a troublesome task as historically this region has been a melting pot of various cultural communities, and the diversity is somewhat still alive to date. Certainly, few cataclysms are still pressing the standing conformity and communal congruence among communities. Passing all the hectic years during British colonial and Pakistani quasi-colonial period, Bangladesh, after the emancipation from exploitation in 1971, was about to thrive. However, the ghost of colonial regimes is still hunting the society. Politics of piety was not ended by forming so-called "secular Bangladesh". Rather, it has gained more success and vigor, and in the meantime, digital media has been empowering political Islam and feeding communal appetite of many Muslims. Digital public sphere in Bangladesh has two contending sides: (a) some use it for the betterment of greater humanity; and (b) some to bring down social serenity.

For all these reasons, this unique virtual space of public discourse having immense mass popularity demands some serious investigation along with its impact on religio-political communication should be done. Yet, no discussion and articulation on this field is present in Bangladesh academia. Therefore, this study, extrapolating "digital public sphere" as a neologism, reveals how dominant Muslim community interacts with religious minorities in digital discourse take place in online public sphere, and its impact inside and outside cyberspace. In this regard, three primary religions: Hindu, Buddhist, and Christianity along with other sub-groups, such as Islamic sects and atheists have been considered as religious minorities whereas Muslims constitutes the dominant religious group in Bangladesh.

\section{Conceptualizing Digital Public Sphere}

The concept of digital public sphere constitutes of two separate features: digital, and public sphere. Digital refers to the electronic technologies those generates, stores, and processes data. The analogue technology functions based on electronic signals whereas data in digital technology is transmitted through satellite or fiber optic, and data processing has two states: positive and non-positive those are represented by 1 and 0 respectively (Rouse, 2018). Digital communication system includes video conference, mobile, virtual reality, fax, online platform, etc. 
The term "public" has at least four different meanings: (a) physical space used by commoners, e.g. park, city squares, etc.; (b) idea of public and private in terms of interest, concern, decision and legitimacy, e.g. individuals have private life and pubic life; (c) public is they who participate in social events or forms of expression, e.g. reading public; and (d) aggregate views and actions of individuals, e.g. public opinion. The concept of public sphere on the account of European Enlightenment was first proposed by Jürgen Habermas in his phenomenal work The Structural Transformation of Public Sphere (1962). To conceptualize "public sphere", he came up with an idea of "a sphere of open (public) spaces and communication where a public discourse on matters of common concern can take place and lead to the formation of an opinion on part of the public of citizens that in turn may influence political decision making" (Gripsrud et al., 2010). Researchers attempt to define digital public sphere:

\footnotetext{
....as a communicative sphere provided or supported by online or social media-from websites to social network sites, weblogs and micro-blogs-where participation is open and freely available to everybody who is interested, where matters of common concern can be discussed, and where proceedings are visible to all. (Schäfer 2015:322-328)
}

Public discourse is one of the pivotal components of public sphere. Such discourses encompass a range of issues regarding politics and policy, social phenomena, etc. Public sphere and public discourse, however, have transformed radically after the so-called Fourth Industrial Revolution or 4IR. Unlike the previous faces of movements and public opinion, contemporary discourses are exceedingly virtual rather than physical. The sharp and clear line between public and private sphere has also becoming blurry due to the overlapping of each other in digital age. Although the boundary is being challenged and violated, however, it is still clear in terms of spatial distinctions (Warner, 2002). Publics in the $21^{\text {st }}$ century have become netizens (a portmanteau of the words "internet" and "citizen") who dwell in cyberspace initiating a new phenomenon called "cybersociety". The cybersociety as a new social formation is based on computer-mediated communication or CMS (Jones, 1998). This new kind of society has few extraordinary features, such as it denies physical space rather located in digital cyberspace, communication is mediated and simulated, at the same time intense, diverse and inclusive, netizens are represented by avatars, discourses are mostly textual in nature, identities are constructed. Although there is a debate among intellectuals whether virtuality is disparaging or enhancing real life, the emergence of this unique "dualistic" community has, to some degree, affixed a new dimension in social mobility (Bell, 2001). 


\section{Nature of Bangladesh Digital Public Sphere}

In Bangladesh, a significant paradigm shift has been noticed narrowly from the 2000s when internet service was started reaching social individuals. A remarkable inclination of netizens happened in last decade. The individual internet users were 1 per cent of the total population in 2006, but in 2016, the number surged eighteenfold and reached at 18.247 per cent (World Bank, 2016). With the inflation of online community, internet platforms have also started generating significant outcomes in public life. Prior nature of social discourse has changed dramatically with the radical penetration of digital. In this regard, digital public sphere is that public sphere which has been digitalized or located within digital communication system.

The heavy influx of individuals as internet denizens, the contemporary digital networking platforms, such as social media and online forums, have become extremely crowded in Bangladesh. Diverse issues are being discussed regularly among cybercommunities dwelling in these platforms. Digital inhabitants are getting stronger in terms of influence in social and political issues, and pursuing and influencing policies through discourse. Distinctive demographic nature (income, age group, sex, education level) of new media users has been generated perceived originality of Bangladesh cybercommunity. On the other hand, penetration of digital services is rocking existing public spheres and bagging potential consumers and clients. Therefore, it is at first imperative to investigate the true features of both Bangladesh digital inhabitants who are active in digital public sphere and formulate contents.

Public and counterpublic: The notion of public is introduced previously but it demands elaboration. In general, a public means the totality of population of nation, state, community, etc. However, public is the accumulation of individuals who assemble in a visible space, participate in discourse, and circulate ideas. On the contrary, counterpublic is the sum of individuals those stand against public and identify themselves as a separate entity. Warner (2002) defines counterpublic as:

...not merely a subset of the public, but constituted through a conflictual relation to the dominant public. They are structured by different dispositions or protocols from those that obtain elsewhere in the culture, making different assumptions about what can be said or what goes without saying. (Warner, 2002:413-425)

Online platform constitutes with both unique public and counterpublic. Every discourse in digital public sphere usually produce a large volume of text generated by two battling oppositions. From Warner and other observations, several key primary features of Bangladesh digital public can be identified: 
a. Self-organized: Public in digital media come as a collection of individuals and form discourse of issues. In Bangladesh, after suitable issues, digital publics constructs diverse discourses to express their views, often to initiate public opinion aiming at policy change. Therefore, it is evident that more than intentional arrangement, public sphere in digital media is mostly self-organized by realistic events.

b. Relations among strangers: In digital public sphere, individuals, except some special cases, hardly know each other in a larger discursive ground. It has been taken for granted that one cannot and should not be introduced with thousands of other individuals to participate in a common discussion. In public posts of social media and blogposts, or interactive websites, strangers come and argue with others spontaneously barely knowing each other.

c. Temporality and engagement: Amusingly, durability of digital discourses generated by online publics in Bangladesh are not so long. Rather, with the penetration of new events, these public become forgetful about the past discourse, and leaving that behind, they further engage in another one. Irrespective of the nature of public as well as issue, this has been a common tendency perceived in Bangladesh digital public sphere.

Alternative discourse and counter hegemony: Digital publics in Bangladesh online frequently play with alternative discourses what is intentionally and unintentionally avoided in physical public sphere due to socio-political reasons. Although there always have been the question of politicization and polarization of digital media, but it provides a common ground to the apolitical for expressing views and opinions. Polarization is often indicated in two specific senses: (1) political polarization of Awami League (AL) vs Bangladesh Nationalist Party (BNP); and (2) religious polarization of Muslims vs others. It has been said that such occupying tendencies of dominant socio-political and social-religious ideologies are preventing Bangladesh digital public sphere from being a full-fledged alternative discursive platform for public. However, it is a primary feature of discourse that there should be two or more contending ideas and publics (Khan \& Makbul, 2014). Monopolization of ideas is an indication of moribund public sphere. In this regard, contemporary digital public sphere is counter-hegemonic entity which has been being in formation from the past few years and lessening the impact of prior dominant social and political institutions, such as mainstream media, political parties, and non-governmental agents. 
Making of a Counter public sphere: Although it is hard to announce digital discursive space as a proper counter public sphere, but it is in the making. Failure and crackdown of offline public sphere drive the potential participants toward online. Freedom of speech and impactful intelligentsia both, to some degrees, are threating for any government so that they are often been shut by any means (Russel, 1996). Social networking sites, blogospheres, streaming sites, and numerous websites in Bangladesh were and are also becoming the hub of free speech those often go against governmental policies and personnel. Therefore, in Bangladesh, fearing public outcry and chastise, it has been alleged that government is continuously introducing regulations, such as Section 57, Digital Security Act 2018 to curb freedom of speech and prevent digital media of becoming a forceful and effective counter public sphere that not only would dismiss real-life public sphere but also could threat governmental authority (Saha, 2017; Amnesty International, 2018). Considering cyberspace a new "counter public sphere", the unequal participation of religious groups can be seen easily. In this regard, Muslims play the dominant role whereas other religious minority communes seem relegated.

\section{Bangladesh Religious Minorities: Populace and Propensity}

The word "minority" itself is has a negative connotation that indicates the opposite to majority, and in conventional sense, means the weaker group of people in a society (Mandal, 2004). Minority group, apart from merely numerical assumption, refers political power. From sociological aspect, a minority group is disadvantaged as compared to the dominant group of a society that possess more wealth, prestige and power, and these reasons manifest the group solidarity among the members of minority community (Giddens et al., (2014). Bangladesh, like its other counterparts, is hosting a good number of religious minorities. Of them, three are more important as well as discussed: Hindu, Buddhist, and Christian. Although, despite of these major religious minorities against Islam as the dominant religion in Bangladesh, several fractions such as Shia, Bahais, Ahmadi communities exist even in Islamic belief system along with animist, agnostic and atheist those are also considered as marginalized religious groups. Of these communities, the number of members is between few thousands to 0.1 million (BDHRL, 2016). A comparative scenario of religious population has been illustrated in the Table 02:

Table 02: Religious Population in Bangladesh 1981-2011

\begin{tabular}{|l|l|l|c|c|}
\hline \multirow{2}{*}{ Religious group } & \multicolumn{4}{|c|}{ Population percentage in census years } \\
\cline { 2 - 5 } & 1981 & 1991 & 2001 & 2011 \\
\hline
\end{tabular}




\begin{tabular}{|c|c|c|c|c|}
\hline Muslim & 86.65 & 88.31 & 89.58 & 90.39 \\
\hline Hindu & 12.13 & 10.52 & 9.34 & 8.54 \\
\hline Buddhist & 0.62 & 0.58 & 0.62 & 0.60 \\
\hline Christian & 0.31 & 0.33 & 0.31 & 0.37 \\
\hline Others & 0.29 & 0.26 & 0.15 & 0.14 \\
\hline
\end{tabular}

Source: Bangladesh Bureau of Statistics (BBS). (2014). Bangladesh Population and Housing Census 2011.

Dhaka: Ministry of Planning, Government of the People's Republic of Bangladesh. p. xiii

Table 02 illustrates the population percentage based on four major religions. Muslims constitute the largest portion of populace (90.39\%) in contemporary Bangladesh, whereas Hindus, with a reducing share in total population from 12.13 per cent in 1981 to 8.54 in 2011, has secured its position as second largest religious community as well as largest religious minority group. In addition, the falling percentage of Hindu population is mostly due to their lower fertility rate than the Muslims (Barakat et al., 2011). On the other hand, Buddhist and Christian communities are relatively smaller than their counterparts, and their contribution to the total populace of the country has been dwindling through years, Table 02 shows. Few animists and smaller religious sects constitute only 0.14 per cent of the population. It is important to mention that seculars and atheists are treated as minority groups because of their ideology and (dis)belief.

Interestingly, the declining Hindus are backed up by few reasons. Ongoing violence, often premeditated as well as state-funded, on a regular basis, and constructing a culture of fear cumulatively driving them to become expatriate. From 1964 to 2013, according to Abul Barakat, a distinguished researcher, 11.3 million Hindus left Bangladesh due to religious persecution and discrimination. During 1971-1981, the daily migration rate of Hindus was 512 whilst between 2001 to 2011 the rate reached at 774. Experts even draw an assumption that following this inclination of exodus, there would be no Hindus in Bangladesh after 30 years (Hassan, 2016).

Buddhist community in Bangladesh has a long historical legacy dated back to more than two millennia. However, currently, most Buddhists in Bangladesh are the member of indigenous communities, such as Chakma, Marma, Garo, etc. concentrated in Chittagong Hill Tracts. They are mainly Theravada-Hinayana Buddhists. On the other hand, Christians are mainly Roman Catholic and dwelling sporadically in different parts of the country (BDHRL, 2017). Buddhist population rose from 0.774 million in 2001 to 0.890 million in 2011 whereas Christians from 0.389 million in 2001 to 0.447 million in 2011 (BBS, 2011). A recent influx of Rohingyas added another one million Muslim population although they would not be counted as the citizen of Bangladesh. 


\section{Religions in Digital Public Sphere}

Digital piety in Bangladesh is on the rise. Unregulated information has simultaneously been empowering and threatening modern society. When access to media is open and everyone is a media has undoubtedly some consequences. Religious practices in digital media, to some degrees, provide spiritual relaxation to the true pious. On the contrary, digital public sphere in Bangladesh has already become heaven for the separatists and religious extremists to ignite communalism along the religious fault line. Therefore, how public and religions interplay in digital public sphere has been analyzed from two different perspective in the context of contemporary Bangladesh.

Religious contents: A variety of digital contents, such as photos, writings, audio, audiovisual, digital documents, links, etc. play their distinctive roles in digital public sphere. Almost all the contents, except few websites, are user-generated as well as interactive in terms of participation and discourse. To be more precise, in varied websites including social networking sites and blogs, three mother categories of digital contents are evident: (a) written text; (b) photo; and (c) audio and audio-visual. They have their own usability and contextual meaning. Written text, for an example, is suitable to start a discussion, or describe something, or address someone. On the other hand, in Bangladesh digital platform, photo most often contains self-representation and virtual showoff, evidence of a discourse, or troll to criticize or dishonor a person or practice. Video, in contrast of motionless contents, provide some action, and most of them are used for infotainment.

In contemporary time, digital public sphere of Bangladesh is becoming heavier with swift invasion of religious, in other words, Islamic digital contents in these three aforementioned forms. Astoundingly, presence of contents regarding other religions are extremely insignificant to mention about as zealots of Muslims often prevent the minorities to do so. As religions are following their followers till digital platform, Bangladesh netizens are embracing their offline piety in digital platform too. Therefore, cyber-Islam has been becoming more prominent in digital public sphere to with the help of its devotees marginalizing other believers. A general overview of Islamic contents under the veil of digital popular culture has been demonstrated in Table 03:

Table 03: Islamic Contents in Bangladesh Digital Media

\begin{tabular}{|c|l|l|}
\hline $\begin{array}{c}\text { Types of } \\
\text { contents }\end{array}$ & \multicolumn{1}{|c|}{ Islamic contents } & \multicolumn{2}{|c|}{ Important sources of contents } \\
\hline $\begin{array}{c}\text { Written } \\
\text { text }\end{array}$ & $\begin{array}{l}\text { Hadith, Islamic blog, Quranic text, } \\
\text { Islamic sermon, story, novel, }\end{array}$ & $\begin{array}{l}\text { Blog: Quarn-er Alo } \\
\text { Islam-er } \quad \text { Alo } \quad \text { (https://quraneralo.com), } \\
\text { (http://islameralobd.com); }\end{array}$ \\
\hline
\end{tabular}




\begin{tabular}{|c|c|c|}
\hline & Islamic book & $\begin{array}{l}\text { Literature: Pathagar (http://pathagar.com), } \\
\text { Islam.net BD (http://islam.net.bd); Text: Android } \\
\text { apps of digital Quran and collection of Hadith }\end{array}$ \\
\hline Photo & 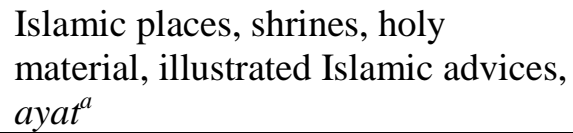 & $\begin{array}{l}\text { Facebook pages: Preaching } \\
\text { Islam(https://bit.ly/2QaJ47U), Islam O Muslim } \\
\text { (https://bit.ly/2QVJTH5) }\end{array}$ \\
\hline $\begin{array}{l}\text { Audio and } \\
\text { audio- } \\
\text { visual }\end{array}$ & $\begin{array}{l}\text { Waaz }^{b}, \text { boyan }^{c}, \text { khutbah }^{d}, d u a^{\mathrm{e}}, \\
\text { oration, Islamic discussion and } \\
\text { lecture, Urdu, Arabic and Bangla } \\
\text { Islamic audio }\end{array}$ & $\begin{array}{l}\text { Video: Islamic TV (https://bit.ly/2Q9WNMd), } \\
\text { Islamic Bangla Waz (https://bit.ly/2CG1V7v) } \\
\text { Audio: Recording of waaz, Hamd o Naat } \\
\text { Ghazal }^{g} \text {, } \text { tilawat }^{h} \text {, lecture. }\end{array}$ \\
\hline
\end{tabular}

Source: Prepared by the Researcher

Table 03 shows a range of digital contents purvey Islamic sentiments to its exponents. Among these, written text, such as blog post or Facebook status are the most popular and widely used digital contents by cyber-dwellers which generate debates among them regarding religious issues. Enthusiasts participate in such discourse and uphold Islamic ideals, often mixing up with their personal views in the name of Islam. Islamic literatures and myths often activate their inner religiosity. The individuals who are superior in religious knowledge or social status often work as the opinion leaders in preaching spirituality and ideas, often fabricated. On the other hand, devotees admire and share photos regarding holy place and things, such as footprints of the Prophet (PBUH), miracles of Allah or Quran or Islam. Most of the time, these images are engineered to espouse either religious devotion or social disorder. Images illustrating various ayats are also popular among the followers. In contrast, doctored photos, intending to spread communal hatred, are circulated by culprits as well ignorant generate chaos.

The arrival of religious contents in digital media is closely linked with offline popular culture. Bangladesh popular culture is gradually deriving Islamic ideas (behavior, norm, perpetuity, holiness, etc.), and substances (clothing, rite, practice, symbol, etc.). Previously, considering the appeal of popular culture, Riaz and Naser (2011) illustrates how it plays roles in constructing and shaping people's identity and discourse. Meanwhile, the link between popular culture and mushrooming Islamic sentiment in contemporary Bangladesh is apparent. Islamic fictions are surpassing secular and other essential literatures both in popularity and sale. Even Islamic fiction writer Kasem Bin Abubakar was featured by national and international media as one of the most decisive novelists in Bangla literature (AFP, 2017). Since digital media become available and accessible to all classes of people so the components of popular culture are also shifting its residence. Henceforth, the digitalized versions of Islamic contents as a form of dominant popular culture in Bangladesh 
cybersociety has been emerging hastily. Albeit contemporary thinkers, beyond offline Islamic (counter) public sphere such as Halqa or Taleem, failed in determining the true power and facets of practicing Islam as a remarkable part of popular culture in digital public sphere (Riaz, 2015). Therefore, as Islamic contents are rocking digital public sphere so that other smaller religious groups are facing difficulties in expressing their own voice and practicing different ideologies and beliefs fearing confrontation and repudiation by the dominant culture.

Communication and language of discourse: To comprehend how the religious minorities: Hindu, Buddhist, Christian and other interact with the dominant Muslims in digital public sphere, analyzing the language of their discourse is indispensable. However, such discourse often can be misleading due to the metacommunication ${ }^{\mathrm{i}}$ during the interaction. Considering communication paradox, it has been theorized that individuals often say things without denoting so (Craig, 2016). In the case of co-cultural communication, religious minorities most often conceal and accommodate their language and pattern of communication to maintain congruence with the dominant culture. Therefore, seeking suitable issues to start a discussion and dispelling diverging ideas while communicating with members of Muslim community are apparent in the behavior of Bangladesh religious minorities. Although most of the "inferior" group members try to hide their remarks, however, it often come out in forms of disgust or appreciation, and applause or avoidance.

Verbal language (in case of digital public sphere, it mostly would be non-verbal written language) in communication bears the most importance to determine how one is communicating and maintaining relationships with others. In Bangladesh, minorities are in most cases voiceless or have little to say. Since Islamic sentiments manufacture fear and threat of being oblivion among minority members so that they most often search for the way of sustaining cohesion with the majority group. To preserve healthy relationships with Muslims in Bangladesh, referring Orbe's (1998) remark, minority community members tend to follow three distinctive ways: (a) assimilation; (b) accommodation; and (c) separation. However, the act of assimilating behavior and communication typically cannot come about as minorities preferably are unwilling to give their own cultural rewards. On the other hand, being separated from majority group would only bring alienation and misfortune, and perceiving that they somehow try to make a tie with their "superiors". Therefore, as the ultimate appropriate option, members from almost all the religious minority groups are more 
prone to accommodate their behavior and language pattern according to the choice of majority Muslims.

The tendency of accommodating communication behavior and use of language is influenced by certain phenomena: power, position, and possession. In this regard, Bangladesh Muslims, occupying more power, superior positions and immense possessions, surpass other religious groups in all facets of social life. For that reason, minorities try to adapt the way of communication what Muslims would like to get their "mercy" even in cyberworld. Surrounding dominant Muslim society often shapes the thought, writing, and other necessary aspects of interaction of minorities (Griffin, 2012). This is how social power mediate and determine the digital discourse and communication between majority and minority in Bangladesh society. Habermas (1977) referring Hannah Ardent posits that "power is not the instrumentalization of another's will, but the formation of a common will in a communication directed to reaching agreement" initially ignores the face of coercive power through communication (e.g. order, chastise) which is a common tragedy in religious co-cultural communication context of Bangladesh. On the contrary, all the religious groups nevertheless do not practice or act upon the same ways mentioned earlier. Rather, their interrelationships with dominant Muslim community based on language and communication varies in a noticeable range. Figure 01 validates this statement:

Figure 01: Communication Pattern between Religious Groups in Bangladesh

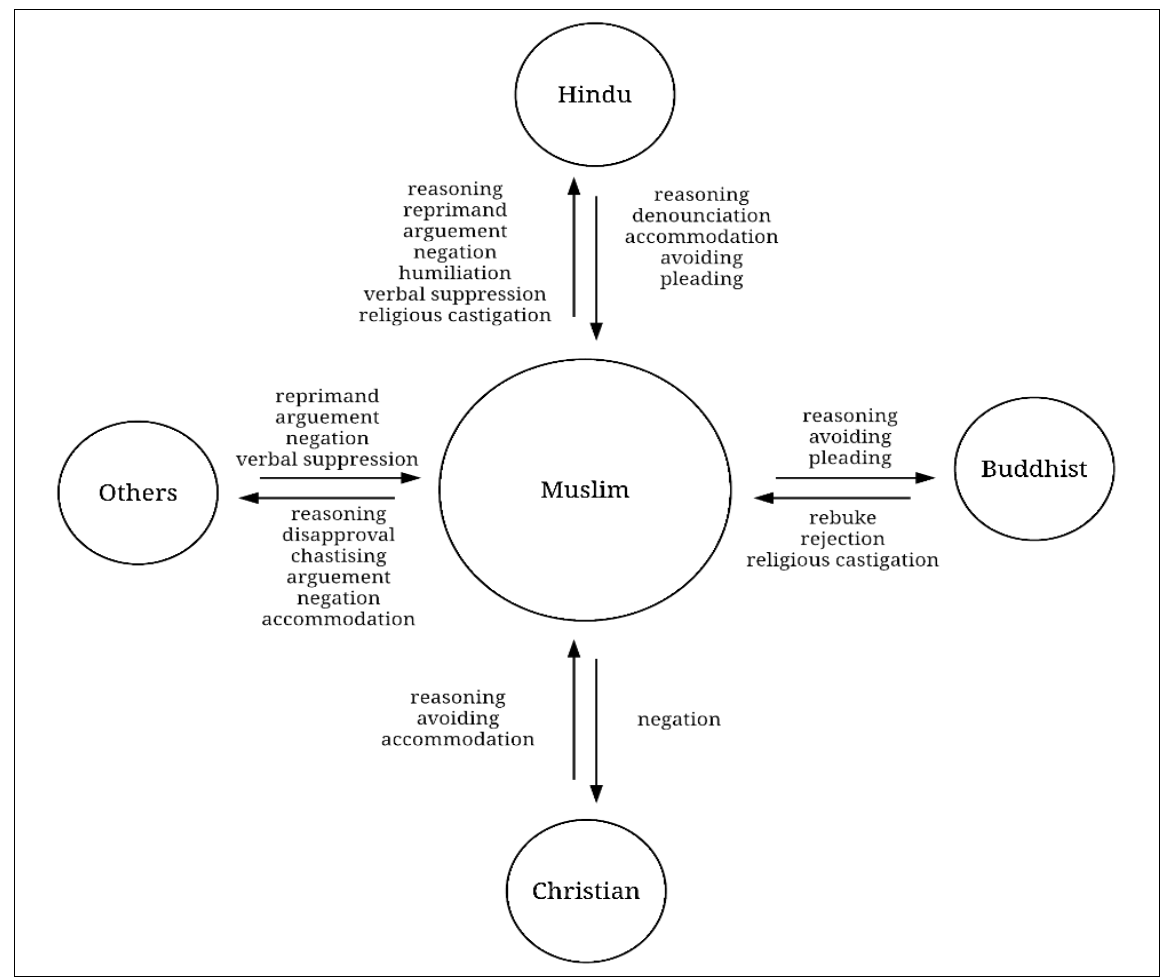


Figure 01 shows the communicative interplay between Muslims and other religious groups in Bangladesh. Firstly, Hindus as the second largest religious community maintain diverse relationships with their majority counterpart. Muslims maintain the most hostile relation with Hindus due to not only religious matters but also regional and global politics, and historical legacy. Fierce Muslims in digital discourses often address Hindus as Malu $u^{\mathrm{j}}$, pagan, bidhormi ${ }^{k}$, jahannamil, etc. pejorative terms. Yet, Hindus have to compromise more in order to form a positive tie with authoritative Muslims. Even, members of the denominations often join or want to join the dominant opinion group as well as Muslim cluster intentionally committing error as they fear of being neglected and isolated (Berger, 1995). Secondly, Buddhists and Christians more often, perhaps intentionally, remain out of the religious discourse and dispute in digital public sphere. Two probable explanations of why they prevent themselves to be involved in any religious confrontation can be: (a) their minimal population size comparing the Muslims or even Hindus; and (b) their aim is a peaceful coexistence rather than hostility and disturbance. However, the humanitarian issue of Rohingya Muslims, who were beaten and expatriated from Buddhists-dominated Myanmar and subsequently entered Bangladesh in seeking shelter, bring the Buddhist community residing within the state boundary into discourse. In practice, they have no link and business in this religio-political game.

On the other hand, according to the communication diagram (Figure 01), it is perceivable that Muslims nourish the feelings of repugnance and disdain against atheists and seculars of Bangladesh based on contingent factors that these "irreligious people" (popularly known as nastik) might spoil the essence of Islam and its holy spirit. In fact, seculars and atheists in Bangladesh are not the promoters of religious separatism and zealots at all. Analyzing the communicative pattern of religious groups, it is evident that digital public sphere has been empowered Muslims to bolster their prior domination upon other religious co-cultures.

\section{Religious Minorities in Digital Public Sphere}

Religious minorities, same as in offline, are pushed to the margin by dominant discourses generated by influential group. Digital religious contents other than Islam are too scant. Photos, videos and writings in social networking sites promoting or featuring various yearly cultural as well as religious occasions, such as Mangal Shobhajatra ${ }^{\mathrm{m}}$, Puja ${ }^{n}$, etc. are sometimes brutally criticized by neo-Islamists emerged in recent times those are mostly new 
generation youths. Alongside other provocations, two necessary propensities, those are being emerged, fostered and promulgated amid society, have been yearning proper disclosure.

Strategic disorder: Digital disinformation nowadays has been trying to expel the serenity and congruence among religious communities, and therefore denying the legality and evicting religious minorities from Bangladesh soil. Some fierce incidents of communalism, sparked by rumors and spread from digital media, have been meticulously plotted by perpetrators. In digital age, every individual can become a decisive media either in preaching peace or bitterness. In Bangladesh, Muslim sentimentalists and miscreants are failing in incorporating other believers for a peaceful coexistence. Some remarkable but heinous examples of strategic vandalism upon religious minorities, those took place in different areas of Bangladesh in different timelines, have been given in Table 04.

Table 04: Disinformation and Strategic Mayhem on Religious Minorities 2012-2017

\begin{tabular}{|l|l|l|l|}
\hline \multicolumn{1}{|c|}{ Incidents } & Victims & \multicolumn{1}{|c|}{$\begin{array}{c}\text { Reasons of the } \\
\text { incidents }\end{array}$} & \multicolumn{1}{c|}{ Behind the scene } \\
\hline $\begin{array}{l}\text { Ramu } \\
\text { Violence }\end{array}$ & Buddhists & $\begin{array}{l}\text { Uttam Barua, a } \\
\text { Buddhist posted a } \\
\text { photo stepping foot } \\
\text { on Quran }\end{array}$ & $\begin{array}{l}\text { Allegation was false but to incite religious outcry } \\
\text { to vandalize Buddhist temples and locality, and the } \\
\text { photo was doctored by two Muslim men }\end{array}$ \\
\hline $\begin{array}{l}\text { Pabna } \\
\text { Attack } \\
2013\end{array}$ & Hindus & $\begin{array}{l}\text { Rajib Saha maligned } \\
\text { Prophet (PUBH) in a } \\
\text { Facebook post }\end{array}$ & $\begin{array}{l}\text { Hindu-boy was framed with the anti-Islamic FB } \\
\text { page scrupulously, and culprits circulate false } \\
\text { photocopies with rumors to incite mass hysteria } \\
\text { before the attack }\end{array}$ \\
\hline $\begin{array}{l}\text { Comilla } \\
\text { Attack } \\
2013\end{array}$ & Hindus & $\begin{array}{l}\text { Two Hindu youths } \\
\text { insulted Prophet } \\
\text { (PUBH) in a FB } \\
\text { post }\end{array}$ & $\begin{array}{l}\text { Fake rumors were carried by and ignite Islamic } \\
\text { sentiment to unleash a 20-min ultimate damage on } \\
\text { surrounding Hindu community }\end{array}$ \\
\hline $\begin{array}{l}\text { Nasirnagar } \\
\text { Violence } \\
2016\end{array}$ & Hindus & $\begin{array}{l}\text { fishermate Hindu } \\
\text { Das belittle Islam in } \\
\text { FB with photo }\end{array}$ & $\begin{array}{l}\text { Someone else than Rasraj did the job to arise } \\
\text { communal hatred among local Muslims against } \\
\text { Hindus to perpetrate such savagery. }\end{array}$ \\
\hline $\begin{array}{l}\text { Thakurpara } \\
\text { Violence } \\
2017\end{array}$ & Hindus & $\begin{array}{l}\text { Illiterate Hindu Titu } \\
\text { Roy insult Prophet } \\
\text { (PUBH) in FB post }\end{array}$ & $\begin{array}{l}\text { No such post was found in his FB id and the } \\
\text { alleged fake id was MD Titu. Imam along with } \\
\text { extremists led the mayhem over surrounding Hindu } \\
\text { villages }\end{array}$ \\
\hline
\end{tabular}

Sources: 25,000 Muslim rioters torch Buddhist temples, homes in Bangladesh (September 30, 2012). RT. Retrieved from: https://bit.ly/2nbJZs4

Topu, Ahmed H. K. (November 03, 2013). Hindus attacked in Pabna. The Daily Star. Retrieved from: https://bit.ly/2LzigOl

Hindu households, temple attacked in Bangladesh (May 05, 2014). The Times of India. Retrieved from: https://bit.ly/2EwEyyq

Manik, Julfikar Ali, \& Barry, Ellen (November 02, 2016). Hindu temples and homes in Bangladesh are attacked by Muslim crowds. The New York Times. Retrieved from: https://hyti.ms/2GzIvoO

Badal, Liakat Ali (November 10, 2017). Mob sets upon Hindu village over rumoured Facebook post. Dhaka Tribune. Retrieved from: https://bit.ly/2CqKQhK 
Table 04 shows four categories of (dis) information of the biggest five incidents of religious bigotry took place in Bangladesh during the last six years and those are shaped by and transmitted from digital public sphere and digital media and cause offline mayhem. As Hindus are the largest minorities in Bangladesh, and due to political reasons, they are the most persecuted religious groups so that they have become the utmost victim of such tensions and vandalism. Surprisingly, all the act of digital disinformation derived from online public sphere have followed a specific pattern, and the accomplishment and outcomes are the same as well as predictable: making the minorities psychological refugee.

Psychological refugee: Being refugee, both external and internal, has been becoming normal in contemporary world. The underlying reasons of seeking further shelter are manifold; often it is coercion and manipulation, often climate change, and other issues. However, beyond physical refuge, another significant metamorphosis in psychic dimensions of social groups has been ignored in academic field. In present Bangladesh, the process of making psychological refugee to the religious co-cultural communities has reached at its peak. The most common feature what these minority group members feel that they might not belong to this country as a "rightful citizen", rather a "second class citizen". Thus, a fluctuation has been happening covertly among these communities, and they are gradually becoming either psychologically fugitive or immigrant. As the last process, they leave the country for forever. Growing Hindu expatriation indicates the truth of this proposition. Besides, National Human Rights Commission (NHRC) declares that religious minorities are the most persecuted in Bangladesh (Hasnat, 2017).

Humiliation in digital public sphere where the minorities cannot obtain suitable space to flourish their belief or scope to express their mind, these tragedies cumulatively are driving them in social alienation. Regardless the importance of their views and opinions, those are mostly remained either unexpressed or subjugated or denied by the dominant voice. Postulating "fear of isolating oneself" as an integral part of public opinion, Noelle-Neumann designates it as the point where individual is vulnerable, and where social groups can punish him for failing to toe the line (Noelle-Neumann, 1974). Therefore, in formation of public opinion, minority voice is frequently denied in front of Muslim's. Fearing social exclusion and other plausible deprivation, members of religious denominations remain silent. A strict psychological filtering of behavior, language, tone, and expression works among these 
members which makes them more inferior, suppressed, and conquered (Noelle-Neumann, 1991).

\section{Conclusion}

Harboring zealots against neighbors cannot bring anything positive and benevolent for a society, and to perceive this simple cause-and-effect relation, no one need to be researcher. Digital media in Bangladesh once showed some promises to fill up the information as well as social gaps between individual to individual and community to community, but those are now becoming mirage. Rather, digital contents, besides tremendous positive effects, are persistently producing social unrest inciting crowd; discourses initiated and controlled by dominant group in digital public sphere is marginalizing minorities, othering the contending beliefs, and expelling alternative voices. Orthodoxy governing online religious climate is breeding the seeds of hatred against smaller religious cliques those trigger communal violence (Mina \& Naher, 2018).

Contemporary digital public sphere of Bangladesh is either enduring a heavy Islamization or turning into an "Islamic digital public sphere" and rendering a confrontational public sphere. Voices of other denominations could be prevailed in cyberspace if it was truly democratic in nature. Muslims are becoming the effective public whereas minority groups might not have the ability to be successful counterpublic. Therefore, Bangladesh digital public sphere would be a ground of Islamic domination over other religious communities. Although these pessimistic propensities and the act of dreadful sectarianism germinated in online often supersedes the real virtues of the digital public sphere, the instances of religious tolerance, constructive discourse and outcomes are also ample which might be the effective instruments to bind the social communities together. In fact, a society based on humanity eradicating all artificial differences of human being should be established through digital media. However, in contemporary course of actions, digital public sphere, highly used by segregationists, is perceived taking a wrong turn towards religious confrontation. 


\section{Reference}

25,000 Muslim rioters torch Buddhist temples, homes in Bangladesh (September 30, 2012). RT. Retrieved from: https://bit.ly/2nbJZs4

AFP (April 26, 2017). Islamic romance novels set hearts aflutter in Bangladesh. Daily Mail. Retrieved from: https://dailym.ai/2RnD7JF

Amnesty International (November 12, 2018). Bangladesh: New Digital Security Act is attack on freedom of expression. Retrieved from: https://bit.ly/2EXTJRA

Badal, Liakat Ali (November 10, 2017). Mob sets upon Hindu village over rumoured Facebook post. Dhaka Tribune. Retrieved from: https://bit.ly/2CqKQhK

Bangladesh Bureau of Statistics (BBS) (2011). Population and Housing Census 2011. Dhaka: Ministry of Planning, Government of the People's Republic of Bangladesh. p. 85

Bangladesh Bureau of Statistics (BBS). (2014). Bangladesh Population and Housing Census 2011. Dhaka: Ministry of Planning, Government of the People's Republic of Bangladesh. p. xiii

Barakat, Abul, Hussain, A. A., \& Hossain, Md. I. (2011). Mismatch of Minority Population in Bangladesh: Population Census vis-à-vis Nation Voter List. Bangladesh Journal of Political Economy, 27 (1 \& 2). Retrieved from: https://bit.ly/2EUVaQV

Bell, David (2001). An Introduction to Cybercultures. London: Routledge. p. 93

Berger, A. A. (1995). Essentials of Mass Communication Theory. London: Sage Publications. p. 69

Bureau of Democracy, Human Rights and Labor (BDHRL) (2016). International Religious Freedom Report for 2016: Bangladesh. United States. Retrieved from: https://bit.ly/2LInKzy

Bureau of Democracy, Human Rights and Labor (BDHRL) (2017). International Religious Freedom Report for 2017: Bangladesh. United States. Retrieved from: https://bit.ly/2lxajuL

Craig, R. T. (2016). Metacommunication. In K. B. Jensen, E. W. Rothenbuhler, J. D. Pooley and R. T. Craig (ed.). The International Encyclopedia of Communication Theory and Philosophy. doi: www.doi.org/10.1002/9781118766804.wbiect232

Giddens, A., Duneier, M., Appelbaum, R. P., \& Carr, D. (2014). Introduction to Sociology ( (th $^{\text {ed. }}$ ). New York: W. W. Norton \& Company, Inc. p. 246

Griffin, Em (2012). A First Look at Communication Theory ( $8^{\text {th }}$ ed.). New York: McGraw Hill. pp. 394-396

Gripsrud, Jostein, et al (ed.) (2010). The Idea of Public Sphere: A Reader. United Kingdom: Lexington Books. pp. xiv-xv

Habermas, J., \& McCarthy, T. (1977). Hannah Arendt's Communications Concept of Power. Social Research, 44 (1), 3-24. Retrieved from: http://jstor.org/stable/40970268

Hasnat, M. A. (December 28, 2017). "Religious and ethnic minorities are most persecuted in Bangladesh". Dhaka Tribune. Retrieved from: https://bit.ly/2CP98Cb 
Hassan, Md. Kamrul (November 20, 2016). "No Hindus will be left after 30 years". Dhaka Tribune. Retrieved from: https://bit.ly/2w4EUtR

Henley, Jon, Sheehy, Finbarr, Swann, Glenn, \& Fenn, Chris (October 27, 2017). Beyond Catalonia: pro-independence movements in Europe. The Guardian. Retrieved from: https://bit.ly/2xtlH13

Hindu households, temple attacked in Bangladesh (May 05, 2014). The Times of India. Retrieved from: https://bit.ly/2EwEyyq

Jones, Steve G. (ed.) (1998). Cybersociety 2.0: Revisiting Computer-Mediated Communication and Community. London: Sage Publication. p. xii

Khan, Amir M, \& Makbul, Nur E. (2014). Drawbacks of Alternative Media in Development: Bangladesh Context. Mediterranean Journal of Social Sciences, 5, 2039-2117.

Mandal, Gobinda, Chandra (2004). Rights of the Minorities: The Case of Bangladesh. In Mizanur Rahman (ed.). Human Rights and Good Governance (pp. 161-174). Dhaka: Empowerment through Law of the Common People.

Manik, Julfikar Ali, \& Barry, Ellen (November 02, 2016). Hindu temples and homes in Bangladesh are attacked by Muslim crowds. The New York Times. Retrieved from: https://nyti.ms/2GzIvoO

Minar, Matiur Rahman \& Naher, Jibon (2018). Violence originated from Facebook: A case study in Bangladesh. Retrieved from: https://bit.ly/2RlVdf4

Noelle-Neumann, E. (1974). The Spiral of Silence: A Theory of Public Opinion. Journal of Communication, 24 (2), 43-51. doi: https://doi.org/10.1111/j.14602466.1974.tb00367.x

Noelle-Neumann, E. (1991). The Theory of Public Opinion: The Concept of the Spiral of Silence. Annals of the International Communication Association, 14 (1), 256-287. doi: http://doi.org/10.1080/23808985.1991.11678790

Orbe, Mark P. (1998). Constructing Co-cultural Theory: An Explication of Culture, Power, and Communication. London: Sage Publication. pp. 89-92

Riaz, Ali (2015). How Did We Arrive Here? Dhaka: Prothoma Prokashan. pp. 69-86

Riaz, Ali, \& Naser, Md. Abu (2011). Islamist politics and popular culture. In Ali Riaz \& Christine Fair (ed.). Political Islam and Governance in Bangladesh (pp. 137-139). London: Routledge.

Roser, Max (2018). War and Peace. Our World in Data. Retrieved from: https://bit.ly/2EIl48p

Rouse, Margaret (December 15, 2018). Digital. Retrieved from: https://bit.ly/2I79SmE

Russel, Bertrand (1996). Power: A new social analysis. London: Routledge. pp. 117-126

Saha, Munmun (2017) Section 57 of ICT Act: A threat to freedom of expression through the suit of defamation. IOSR Journal of Humanities and Social Sciences, 22 (11), 24-27.

Schäfer, Mike S. (2015). Digital Public Sphere. In Gianpietro Mazzoleni et al. (ed.) (2015). The International Encyclopedia of Political Communication. London: Wiley Blackwell. pp. 322-328

Topu, Ahmed H. K. (November 03, 2013). Hindus attacked in Pabna. The Daily Star. Retrieved from: https://bit.ly/2LzigOl 
Warner, Michael (2002). Public and Counterpublics. New York: Zone Books. p. 26

Warner, Michael (2002). Publics and Counterpublics (abbreviated version). Quarterly Journal of Speech, 88 (4), 413-425

World Bank (2016). Individuals Using the Internet. Retrieved from: https://bit.ly/2BGjdB8

\footnotetext{
Notes

a A statement of verse of the Quran varies in length.

${ }^{\mathrm{b}}$ A type of traditional Islamic scriptural commentaries which is delivered by a Pir or Huzur (Islamic clergy) in a public assembly.

${ }^{c}$ Narration or talking on certain issues, often religious ones.

${ }^{\mathrm{d}}$ Sermon delivered from an elevated pulpit (minbar) by a khatib, or Muslim preacher, at Friday prayers and at special celebrations.

e An act of supplicating to Allah, according to Islam.

${ }^{\mathrm{f}}$ A branch of Islamic song developed by National Poet Kazi Nazrul Islam.

${ }^{\mathrm{g}}$ Islamic song in three different languages: Urdu, Arabic, and Bangla.

${ }^{\mathrm{h}}$ Reciting Quranic texts.

${ }^{i}$ Metacommunication is all the nonverbal cues (intonation, body language, gestures, facial expression, etc.) that carry meaning that either enhance or disallow what one says in words.

j A derogatory term, transformed from Arabic "Malun" that means "accursed" or "deprived from God's mercy".

${ }^{\mathrm{k}}$ Irreligious, godless.

${ }^{1}$ The person who is going to hell (jahannam) in afterlife.

${ }^{m}$ A cultural heritage as well as a mass procession which takes place in the early morning of the first day of Bengali New Year.

${ }^{\mathrm{n}}$ A ritual of prayer or devotional worship of deities by Hindus.
} 